\title{
Is the Creative Class a Game Changer in Cities? A Socioeconomic Study on Romania
}

\author{
Alina Maria Pavelea ${ }^{1, *}$, Bogdana Neamțu ${ }^{1}$, Peter Nijkamp ${ }^{2,3,4,5}$ and Karima Kourtit ${ }^{2,3,4,5}$ \\ 1 Department of Public Administration and Management, Babeș-Bolyai University, \\ 400132 Cluj-Napoca, Romania; neamtu@fspac.ro \\ 2 Centre for European Studies, Alexandru Ioan Cuza University of Iași, 700506 Iași, Romania; \\ pnijkamp@hotmail.com (P.N.); k_kourtit@hotmail.com (K.K.) \\ 3 The Faculty of Management, Open University, 6419 Heerlen, The Netherlands \\ 4 School of Architecture, Planning and Design, Polytechnic University (UMP6), Ben Guerir 43150, Morocco \\ 5 Geography and Spatial Management, Adam Mickiewicz University, 61-712 Poznan, Poland \\ * Correspondence: paveleaalina@fspac.ro
}

check for updates

Citation: Pavelea, A.M.; Neamțu, B.; Nijkamp, P.; Kourtit, K. Is the Creative Class a Game Changer in Cities? A Socioeconomic Study on Romania. Sustainability 2021, 13, 5807 https://doi.org/10.3390/su13115807

Academic Editor: Wann-Ming Wey

Received: 27 April 2021

Accepted: 19 May 2021

Published: 21 May 2021

Publisher's Note: MDPI stays neutral with regard to jurisdictional claims in published maps and institutional affiliations.

Copyright: (c) 2021 by the authors. Licensee MDPI, Basel, Switzerland. This article is an open access article distributed under the terms and conditions of the Creative Commons Attribution (CC BY) license (https:/ / creativecommons.org/licenses/by/ $4.0 /)$.

\begin{abstract}
In the wake of current urbanization trends, Creative Class theory has gained much popularity. According to the theory, in order to achieve sustainable socioeconomic growth and citizens' well-being, cities have to attract the Creative Class, who prefer places that simultaneously provide amenities such as tolerance, talent, technology, and territorial assets (the four Ts). Although the theory has been tested extensively in the USA and in Western European countries, few attempts have been made to study it in Eastern Europe. As such, this paper tests Creative Class theory in the case of Romania, which is an interesting country for this study, since it has a relatively low level of urbanization and the population is less mobile compared to Western countries. Our results show that talent, technology, and territorial assets are able to significantly explain the geographical concentration of the Creative Class. However, different types of tolerance have different effects on the concentration of the Creative Class. Nevertheless, when we control for conventional socioeconomic welfare variables, the results change. The variable that has the highest effect on welfare patterns is path-dependency, namely, the previous level of regional and urban welfare registered. Thus, this paper reflects the need for both researchers and practitioners to consider the path-dependency trajectories of socioeconomic health and well-being in urban areas.
\end{abstract}

Keywords: creative class; urban economic growth; post-socialist countries; path-dependency

\section{Introduction}

In a recent study on 'urban empires' Glaeser et al. [1] posit that the welfare profile of cities and urban agglomerations does not follow a rectilinear trajectory, but is dependent on a wide range of background factors. Determinants of the complex dynamics of urban systems may include adaptivity; geopolitical turmoil; entrepreneurship; open-mindedness for new opportunities; place-based Human Capital reflected, inter alia, in educational profiles; medical health care; social capital; innovativeness and creativity [2]. Thus, there is a broad recognition that (the lack of) urban development in various different countries originates from a multifaceted portfolio of interconnected drivers. However, in recent years, one factor has often been regarded as a major successful determinant of innovative and sustainable urban growth, viz. the presence of the Creative Class [3-6].

Although the concept of the Creative Class has often been embraced as an innovative strategy for gaining a new momentum for a sustainable, healthy and happy future of cities, it has also been contested on various grounds. Controversies have arisen, inter alia, around (1) its operational definition (e.g., in terms of the individual or sectorial level of actors, the educational substratum for creativity, and the unjustified belief in the real role of creativity in a professional business environment etc.); (2) the urban seedbed 
conditions (e.g., the cultural amenities in a city, the individualistic-creative attitude vs. social community interaction); (3) the long-run well-being benefits for the urban economy (e.g., the added value as a result of the 'footloose' character of creative people, but their lack of integration with residents and established business). Moreover, it is argued that the supposedly 'bohemian' lifestyle of creative people is only a privilege of the 'nouveau riche' who can afford to enjoy exuberant or non-conventional city behavior. Thus, it is questionable whether Creative Class theory provides a uniform recipe for shaping or generating the ultimate force of growth pathways in the New Urban World [7].

There is abundant literature around the conceptualization, operationalization, application, and policy implementation of Creative Class theory, which was first advocated for by Andersson [8] and later on elaborated and popularized by Florida [3-5]. It is noteworthy that, initially, the concept of a Creative Class was developed as a human-oriented qualification of individuals, but later on extended to groups (the 'Creative Class'), sectors ('creative industries'), regions or cities ('creative spaces'). For illustration, we refer here, inter alia, to $[2,9-18]$.

The relationship between creative people and attractive spaces has been a source of much scientific inspiration [19-21]. If the socioeconomic 'fate' of cities is dependent on the creative spirit of individuals or professional groups, it is conceivable that urban planning should provide those appealing locational conditions that attract creative people in particular. According to Florida [22], places that are attractive to creative people are characterized by four specific locational advantages: tolerance, talent, technology, and territorial assets (hereafter abbreviated as the four Ts). Consequently, urban policies aimed at promoting economic growth through the vehicle of the Creative Class would have to facilitate the creation of the four Ts. Apart from these four factors, another strategic question which arises is: are these four determinants necessary and/or sufficient conditions for accelerated urban growth? This question is important, as in urban economics literature other critical factors often come to the fore, such as highly qualified Human Capital, a political-historical culture which is favorable to a free market or entrepreneurship, or social capital in urban communities, etc.

Creative Class theory has been tested extensively in the USA and in Western European countries [20,21,23-27], but the results obtained vary significantly depending on the data and the measurements used. Moreover, very few attempts to examine the validity of this concept outside of Western contexts have been made. One notable exception is China, where in recent years several Creative Class studies have been undertaken [28,29]. This situation is problematic, as various authors have questioned the extent to which the measures proposed by Florida might work in other contexts and have emphasized the need to adapt it to different national contexts [24]. Thus, our paper addresses Creative Class theory in the case of Romania, a country that has different political-economic background conditions, is less urbanized, and is a country where individuals are less mobile.

Critical studies represent cases that allow the logical generalization of the findings to other cases where it is more likely that the findings will apply [30]. Thus, we argue that the identification of the relationships proposed by the theory in the case of Romania would allow the generalization of the results from Western counties, where the mechanism is more likely to work. Moreover, the recent political events in Romania, such as the referendum on same-sex marriage organized in 2018, provide the opportunity to improve the highly contested measure of tolerance, namely: the Gay Index. Thus, this paper makes a two-fold contribution to the literature: (1) by examining the theory in the context of an Eastern European country which represents an important field of socioeconomic study; and (2) by improving one of the measurements that the original author of this theory uses.

\section{The Creative Class Theory}

Cities face a plethora of challenges. The problems raised by climate change force cities to seek a more sustainable means of achieving economic growth. Furthermore, phenomena such as globalization and digitalization have resulted in an increased global competition. 
The Creative Class theory proposed by Florida [22] provides a strategy that cities can adopt in order to adapt to the new urban dynamics. First, creativity is considered to stimulate urban sustainable development $[31,32]$ as it promotes innovation and creative occupations are less resource intensive [33]. Second, it can help cities succeed in the global competition by reinforcing their position as 'urban ambiance' breeding places, to attract and retain a particular group of people who comprise the "Creative Class", conceived of as the ultimate source of economic growth [22].

The Creative Class is defined as those individuals who have occupations "whose function is to create meaningful new forms" [22] (p. 38), individuals who are, in general, highly mobile. The theory predicts that the Creative Class will move to areas that simultaneously possess four attractive qualities, namely: talent, tolerance, technology and the territorial assets (the four Ts) [22]. However, there is still an ongoing debate concerning whether the creative individuals are more attracted to the presence of amenities (such as those proposed by Florida) or by 'hard' conditions, a term used by Musterd and Gritsai [13] to refer to the classical location factors such as job opportunities or wage levels. Musterd and Gritsai [13] have examined the extent to which the location decisions of highly skilled employees from 13 European cities (both Eastern and Western) were influenced by amenities, 'hard' conditions, or personal networks. They concluded that personal networks and 'hard' conditions are important for the location decisions of highly skilled employees, while soft conditions are of little importance. Similar results were also obtained in other studies conducted in Europe [34-37]. As such, 'hard' conditions may have to be considered as an alternative or complementary explanation for the location decisions of the Creative Class, and is an important element of the present study.

Although the theory has gained popularity among policy makers and politicians, several academic researchers have been critical [38]. Some of the criticisms raised are presented below.

\section{Criticism of the Creative Class Theory}

Glaeser [39] has questioned the originality of Creative Class theory, arguing that it is not fundamentally different from Human Capital theory. According to this line of argument, Creative Class theory is just a new way of quantifying the effect that Human Capital has on economic growth. Florida [22] has addressed this, arguing that only $60 \%$ of the members of the Creative Class have college degrees. According to Florida [22,40,41], the Creative Class is a better measure of skills, compared with the Human Capital approach, as the latter omits some of the individuals who are creative, but have not completed higher education.

Various studies have been conducted in order to determine whether there is indeed a difference between the two classes of theories, or which of the two can better account for development. However, no clear answer has been provided thus far, as different studies have reached contrasting conclusions [27,42-46]. One explanation offered is that it depends on the variables used to quantify economic growth or regional development. As such, Creative Class theory outperforms Human Capital theory when the level of wages is used as a proxy for regional development [23]. However, when population growth is used as a proxy for regional development, Human Capital theory is a significantly better predictor [39]. Nevertheless, Florida [23,41] argues that the number of jobs does not reflect the overall level of development. For example, an increase in the number of low-paying jobs will be reflected as an increase in the level of regional development, which is misleading. At the same time, other studies conclude that the Creative Class contributes to regional development by increasing the level of wages, while Human Capital contributes to regional development by increasing the income level [47]. Therefore, using the level of wages as a proxy for the level of regional development is considered to be more appropriate.

The theory has also been criticized for disregarding the cumulative causation and pathdependent trajectories of development [48]. According to this argument, as a consequence 
of returns to scale, growth will lead to further growth, resulting in a path-dependent urban expansion in the longer run.

The occupations included in the Creative Class have also been questioned. The Creative Class is argued to fail to take into account some occupations that require creativity, for example, airline pilots, ship engineers, or tailors [49]. This is a valid point, as the aforementioned occupations comply with the criteria that Florida employed in selecting the professionals who comprise the Creative Class. The same can be said for other occupations, such as detectives and criminal investigators. At the same time, the inclusion of some occupations, such as those in the financial sector, has also been criticized [50]. As such, the occupations that Florida included in the Creative Class seem rather arbitrary. One alternative to Florida's measurement of creativity has been proposed by McGranahan and Wojan [42]. The main advantage of this recast of the Creative Class is that it objectively classifies jobs as being creative, based on the creativity occupations they require, according to the $2004 \mathrm{O}^{*}$ NET. Some of the most notable changes are the exclusion of some occupations, such as business operations specialists, and other financial specialists, and the inclusion of only the post-secondary teachers.

Probably one of the most controversial elements of the model is the use of the percentage of gay people as a proxy for tolerance. The Gay Index was criticized as being biased, as this measure of tolerance was considered to have resulted from an influential data point (San Francisco), without which the relationship observed would not have been present. However, Florida [22] did test the sensitivity of the results to this data point and concluded that the relationship does not change. At the same time, questions arise regarding the ability to quantify the number of gay people. According to Kačerauskas [51] not all homosexual people self-identify as such. Moreover, the presence of bisexuality seems to point to the fact that homosexuality is a cultural and ethical category rather than physical. Thus, he concludes that it is impossible to quantify the number of gay people.

The measurement used by Florida [4] for talent, namely the number of those with a bachelor's degree or above, has also been criticized. Kačerauskas [51] argues that this is instead a measure of the availability of university education, and a measurement of how prestigious university education is perceived to be. Evidently, this is a legitimate criticism, as it is reasonable to expect that places with more affordable university education will have on average more university graduates.

It should be noted that in a more recent book, Florida [52] acknowledges that his initial proposition on the Creative Class as drivers of economic growth might have overlooked the resulting equity problems in US cities. Some of the most important problems involve the increasing socioeconomic inequality, both between and within cities, and the emerging segregation in the context of urban gentrification. However, for the most part he only analyses these issues in the context of the USA. His theory, however, was also adopted outside of the USA as a policy anchor point. In Europe, for example, the European Union has promoted this approach as a means to achieve economic growth [53] for the heterogeneous countries in Europe. Therefore, a test of the validity of this theory in specific socioeconomic environments is warranted.

In the present paper, we address a different criticism from those already raised in the literature, namely the ethnocentricity of the empirical model, which is biased toward Western countries. In Europe, for example, Western countries are significantly more open toward the LGBTI (lesbian, gay, bisexual, transgender and intersex) community compared with Eastern countries. By assigning a high importance to the percentage of gay people, the results can highly favor Western societies, by offering an exceedingly positive image of their level of tolerance. However, even though Western countries are more open toward the LGBTI community, they can be less open to religious or ethnic differences, a fact that is suggested by the surge of the extreme right-wing parties in countries such as France, the Netherlands, and Germany. That is not to say that the level of tolerance to the LGBTI community is not relevant, but focusing excessively on it could give an unrealistic picture. Moreover, we argue that, in the case of Eastern European countries, the various 
types of tolerance must be considered separately (not as a composite measure), since the correlation between the Creative Class and different types of tolerance can vary. As such, although tolerance to same-sex relationships, for example, might not be correlated with the concentration of the Creative Class, ethnic or religious tolerance could be.

The idea of a Western bias is reinforced by the fact that the theory was developed starting from the case of the USA, which can raise questions regarding the extent to which the proposed measures to promote economic growth would be effective in countries with specific socioeconomic contexts, such as in Romania.

\section{Romania: A Critical Socioeconomic Analysis}

Critical cases represent cases that allow logical generalization of findings to other cases where it is more likely that the findings will apply [30]. We argue that Romania represents a critical case for Creative Class theory.

There are multiple contextual reasons that reduce the chances of the proposed relationship being observed in Romania. The most important ones deal with the level of urbanization and workforce mobility. With regard to the existing level of urbanization, Romania is the least urbanized country in the European Union (slightly over $54 \%$ of the population lives in cities). With regard to the workforce's mobility, which is one crucial tenet of Creative Class theory, we argue that this assumption is not met in Romania. The country has the highest rate of home ownership in the world, with more than $96 \%$ of the homes being owned by their occupants, which considerably reduces the propensity of individuals to migrate.

It should be noted that Nordic countries have also been argued to be critical cases for Creative Class theory [26], because of differences in urban hierarchies, compared to the USA, such as low workforce mobility, strong labor unions and low levels of immigration. All of these factors are also present in Romania, and are connected to urban and economic national contexts. However, we argue that, unlike the Nordic countries, Romania also exhibits cultural reasons that reduce the chances of the relationships being observed. More specifically, in Romania the close ties with families [13] also reduce individual mobility. At the same time, Romania has the highest discrepancy between females and males in terms of transnational labor mobility from the European Union [54]. More specifically, only one quarter of the movers are females. In other words, Romania has the lowest female mobility from the European Union, although in terms of internal mobility the discrepancy is not so large [55].

Besides the reasons that make Romania a critical case, the recent political events in Romania also provide the opportunity to improve the highly contested measurement of tolerance, namely: the Gay Index. In 2018, Romania held a constitutional referendum on same-sex marriage. More specifically, Romanian citizens were asked whether they approved of an explicit provision in the Constitution that marriage is allowed only between a woman and a man, as, before, the Constitution stated that marriage is allowed "between spouses". In other words, the referendum was aimed at explicitly prohibiting any possibility of same-sex marriage. As such, we assume that people who voted "no" during the referendum have expressed their tolerance toward same-sex relationships. Therefore, we argue that this represents an actual measure of tolerance, not merely an estimation of tolerance.

Based on the reasons presented above, the present paper attempts to investigate the relationships proposed by Creative Class theory in the case of Romania, in order to determine, on the one hand, whether the four Ts (talent, tolerance, technology, and territorial assets) are correlated with the geographic concentration of the Creative Class in cities. On the other hand, this paper also investigates whether the Creative Class is a better predictor for regional development compared with Human Capital theory. Thus, this paper aims to provide an answer to the following research questions:

1. Do tolerance, talent, technology, and the territorial assets explain the presence of the members of the Creative Class in the Romanian municipalities? 
2. Is the Creative Class theory a better predictor of regional welfare than Human Capital theory?

These questions will be further put in perspective, methodologically and empirically, in Section 4.

\section{Database and Methodology}

This paper examines the extent to which the theory predicts the presence of the Creative Class and the influence that the Creative Class exerts on the level of regional development in Romania. Given the fact that Florida argues that cities (or metropolitan areas) are the most important actors in the global economy [1], we examined the relationships in the case of two categories of cities, namely the 103 municipalities from Romania and the 41 county capitals, which represent all of the largest cities. It should be noted that by reducing the number of cases to county capitals only, we are in fact reducing the chances of identifying significant results, given that the statistical significance is dependent on the size of the sample [56]. The database and methodological approach will now be described.

\subsection{The Creative Class}

The concentration of the Creative Class was measured in terms of the percentage of people who have creative occupations out of the total number of employees. Given the criticisms regarding the occupations included in the Creative Class, we used two measures for the Creative Class, which differ based on the occupations included. More specifically, on the one hand, we used the occupations (Appendix A) used by Florida [22], and on the other, we used the occupations (Appendix B) proposed by McGranahan and Wojan [42]. One limitation of the study is that the data used was provided by the National Trade Register Office, which only takes into account the private sector. As such, an important part of the members of the Creative Class is not included.

\subsection{The Four Ts}

Talent. Talent is measured as the percentage of highly educated people in the total population registered in 2011, when the last census was conducted.

Tolerance. Multiple measures of tolerance have been used. As such, given the criticism raised regarding the use of the Gay Index as a measure of tolerance, the present paper makes use of an improved measurement. More specifically, tolerance was measured as the percentage of individuals who voted "no" in the referendum organized in 2018 out of the total number of people who could vote.

The religious and ethnic fractionalizations were used as proxies for the religious and ethnic diversity. Although there is not a direct relationship between religious and ethnic diversity and tolerance toward different religions and ethnicities, research shows that the overall share of immigrants of different ethnicities and religions reduce the rejection of immigrants [57] and thus increase tolerance. As such, we assume that a high level of religious or ethnic diversity is an indicator of a high level of tolerance toward different religions or ethnicities. The ethnic and religious fractionalizations measure the probability that two randomly drawn people from a municipality belong to different ethnic or religious groups [58]. More specifically, the ethnic and religious fractionalization was computed as:

$$
\text { Ethnic }=1-\sum_{i}(\text { ethnicity })^{2},
$$

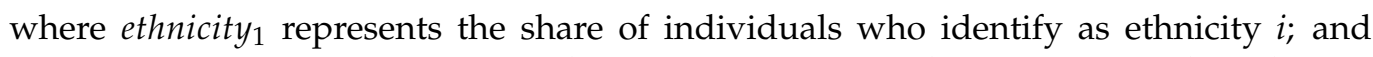
$i=$ Romanians, Hungarians, Roma, Ukrainians, Germans, Turks, Russians or other ethnicity.

$$
\text { Religious }=1-\sum_{i}\left(\text { religion }_{1}\right)^{2},
$$

where religion 1 represents the share of people identified as religion $i$; and $i=$ Orthodox, Roman Catholic, Reformed, Pentecostal, Greek Catholic, Baptist, Adventist or other religion. The ethnic and religious fractionalization takes values between 0 and 1 ; a higher value 
indicates a municipality with a higher level of ethnic or religious diversity. The data regarding the ethnic and religious distribution were retrieved from the National Census conducted in 2011.

Technology. The measure for the concentration of technology is different from the TechPole Index used by Florida [4], in the sense that, for data availability issues, it uses turnover instead of real-output. More specifically, the percentage of national high-technology turnover was multiplied by the high-technology turnover location quotient for each municipality. The NACE codes used are presented in Appendix C.

Territorial assets. The percentage of people employed in restaurants and beverageserving activities (NACE codes 5610 and 5630) was used as a proxy for the level of urban amenities, as it has been used previously by other authors [59]. The data used were provided by the National Trade Register Office.

\subsection{Regional Development}

The regional development level was measured using two measures, namely: a proxy for income, and a proxy for productivity. Given the fact that population or job growth are considered to be inadequate to measure regional development [23], the decision was taken to focus on the level of income. Although the use of wages is more appropriate in this case [47], there is no data available on wage earnings at the level of municipalities. As a consequence, the amount of the income tax received by the municipalities, divided by the total number of people, was used as a proxy for the income level. The obtained result represents the average income tax that citizens pay, which provides information regarding the level of annual income that citizens gain on average. The data were retrieved from the website of the Romanian Directorate for Fiscal Policies and Local Budgeting. The level of productivity of the workforce was measured by dividing the turnover that companies registered at the level of municipalities by the total number of employees. The data used were provided by the National Trade Register Office.

\subsection{Control Variables}

Unemployment. The unemployment level registered by the municipalities in 2018 was used as a proxy for the hard conditions (e.g., job opportunities), which previous studies $[13,34,35,37]$ concluded to be more important to the location decisions of creative individuals compared with amenities. The data were retrieved from the website of the National Institute of Statistics.

Hachman Index. The level of economic diversification was measured using the Hachman Index:

$$
H I=\frac{1}{\sum_{i=1}^{n}\left[\left(\frac{s_{i j}^{s}}{s_{i}}\right) \cdot s_{i j}^{s}\right]},
$$

where $s_{i j}^{s}$ is the ratio of employment in sector $i$ in region $j$ to total employment (all $i$ sectors) in the region $j$; and $s_{i}$ is the ratio of employment in sector $i$ in all $j$ regions to total employment (all $i$ sectors in all $j$ regions). The index takes values between 0 and 1 , depending on the degree to which the regional structure resembles the national structure.

Business density. This was measured as the ratio of firms registered in 2018 per 1000 people.

Path-dependency. As path-dependency and cumulative causation have been argued to be more appropriate explanations for development compared with the Creative Class [47], we control for path-dependency by including in the analysis the level of income and productivity registered in 2008 .

\section{Results and Discussion}

\subsection{The Four T's and the Creative Class in Romania}

The first step in examining the relationships proposed by the theory is to investigate the extent to which talent, tolerance, technology, and territorial assets explain the concen- 
tration of the Creative Class. This was done using ordinary least squares (OLS) regressions. It should be noted that, given the small number of cases, the significance level used is 0.10 , as this is both recommended and used in the case of small samples [60]. The results obtained are presented in Table 1, where the dependent variable is the concentration of the Creative Class, while the explanatory variables are the four T's and the unemployment level, a measure of 'hard' conditions.

Table 1. The four T's and the Creative Class.

\begin{tabular}{ccc}
\hline Explanatory Variables & All Municipalities & County Seats \\
\hline Talent & $0.618^{* * *}$ & $0.587^{* * *}$ \\
& -0.086 & -0.175 \\
Gay tolerance & 0.063 & -0.060 \\
Ethnic diversity & -1.099 & -1.579 \\
& 0.2 & $0.765^{* * *}$ \\
Religious diversity & -5.911 & -14.693 \\
Technology & -0.161 & $-0.760^{* *}$ \\
Territorial assets & -4.559 & -9.749 \\
& $0.230^{* *}$ & $0.257^{*}$ \\
Unemployment & -16.961 & -20.468 \\
$R^{2}$ & $0.119^{*}$ & $0.283^{* *}$ \\
Adjusted $R^{2}$ & -0.239 & -0.772 \\
F & 0.018 & 0.008 \\
& -0.595 & -1.728 \\
& $0.530^{* * *}$ & $0.674^{* * *}$ \\
& $0.496^{* * *}$ & $0.605^{* * *}$ \\
\hline
\end{tabular}

* Significant at the 0.10 level; ** Significant at the 0.05 level; and ${ }^{* * *}$ Significant at the 0.01 level; standard error in brackets.

The model including the four T's and the level of unemployment as predictors for the concentration of the Creative Class in the case of all municipalities appears to partially confirm the relationships predicted by the theory. This model is statistically significant, and the predictors explain 53\% of the variation in Creative Class concentration. The results are in line with what the theory predicts, as talent, technology and territorial assets have a positive effect on the concentration of the Creative Class. The theory is further supported by the results, as the effect of the aforementioned variables is not affected by reducing the number of cases to only county capitals.

As argued, same-sex tolerance is not significantly correlated with the spatial concentration of the Creative Class. However, the other types of tolerance measured, namely: ethnic and religious tolerance, are also not significantly correlated with the concentration of the Creative Class either. This is in line with other research that investigated the connection between ethnic diversity and the Creative Class at the level of neighborhoods [61]. As such, contrary to what the theory predicts, these results suggest that tolerance and diversity are not factors that attract the Creative Class. However, the results change when only county capitals are examined. More specifically, the ethnic and religious tolerance are now significantly correlated with the Creative Class. The ethnic tolerance is positively correlated with the Creative Class, which supports Florida's argument that the Creative Class is attracted by places characterized by tolerance and openness. However, there is a negative effect of the religious diversity on the Creative Class' concentration. One possible explanation could be that the Creative Class is characterized by secular values, which is in line with Florida's work [22]. Therefore, ethnic tolerance does attract the Creative Class, but only in the case of large urban centers. It should be noted that previous research concluded that indicators of openness (foreign born) are positively correlated to the Creative Class in both small and large regions from the Nordic countries, namely: Denmark, Finland, Norway, and Sweden [26]. One explanation for this difference in the results obtained can be the difference in what constitutes large and small cities. For example, the population 
in the second largest city region in Sweden was 856,367 [26], while Iași, one of the largest cities in Romania, registered a population of 323,675.

The results obtained support the fact that the size of the region is relevant for the relationships proposed by the theory, as the predictive power of the model appears to increase. As such, the explanatory variables now account for $67.4 \%$ of the variation in the Creative Class.

Although previous research [34-37] concluded that 'hard' conditions are more important to the location decisions of creative individuals compared with amenities, our results do not confirm this, as the level of unemployment is not significantly correlated with the Creative Class.

\subsection{Skills and Regional Development}

As a complement, and as a contrast, to the four Ts model of Creative Class theory, we now provide a test using traditional Human Capital components. We investigated the correlations between the three measurements of skills used (Table 2). The correlation between the redefined measure proposed by McGranahan and Wojan [42], hereafter called Recast, and the other two measures of skills is low, while the correlation between the Creative Class and Human Capital is considerably higher (0.675).

Table 2. Correlation of the measures of skills.

\begin{tabular}{cccc}
\hline & Creative Class & Creative Class Recast & Human Capital \\
\hline Creative Class & 1 & $0.360^{* *}$ & $0.675^{* *}$ \\
Creative Class Recast & $0.360^{* *}$ & 1 & $0.197^{*}$ \\
Human Capital & $0.675^{* *}$ & $0.197^{*}$ & 1 \\
\hline${ }^{*}$ Significant at the 0.05 level (2-tailed); ${ }^{* *}$ Significant at the 0.01 level (2-tailed).
\end{tabular}

As such, the measures of skill used appear to be different. In the next step we investigated whether these differences translate into different effects on the level of development. The results obtained (Tables 3 and 4) vary based on the cases included. As such, when all municipalities are considered, all measures have a significant effect on income. However, the magnitude and direction of the effect differs. Human Capital has the highest effect, while the effect of the Creative Class is weaker. Contrary to expectations, the Recast has a negative effect on income. Conversely, when only county capitals are considered, both Human Capital and the Creative Class have a significant effect on income, but the difference in the magnitude of the effect is lower. At the same time, the Recast is no longer statistically significant.

Table 3. The measures of skills and regional development. All municipalities.

\begin{tabular}{ccc}
\hline & Income & Productivity \\
\hline Creative Class & $0.254^{* * *}$ & 0.072 \\
& -3.495 & -1736.91 \\
Creative Class Recast & $-0.173^{* * *}$ & -0.144 \\
& -1.611 & -800.546 \\
Human Capital & $0.635^{* * *}$ & $0.295^{* *}$ \\
$R^{2}$ & -3.133 & -1556.72 \\
Adjusted $R^{2}$ & $0.641^{* * *}$ & $0.117^{* * *}$ \\
F & $0.630^{* * *}$ & $0.090^{* * *}$ \\
\hline
\end{tabular}

*Significant at the 0.10 level; ** Significant at the 0.05 level; and *** Significant at the 0.01 level; standard error in brackets. 
Table 4. The measures of skills and regional development. County seats.

\begin{tabular}{ccc}
\hline & Income & Productivity \\
\hline Creative Class & $0.376^{* *}$ & $0.525^{* * *}$ \\
& -5.952 & -1663.29 \\
Creative Class Recast & -0.059 & $-0.239^{*}$ \\
& -2.604 & -727.651 \\
Human Capital & $0.442^{* * *}$ & -0.001 \\
$R^{2}$ & -8.296 & -2318.22 \\
Adjusted $R^{2}$ & $0.554^{* * *}$ & $0.290 * * *$ \\
F & $0.518^{* * *}$ & 0.232 \\
* Significant at the 0.10 level; ${ }^{* *}$ Significant at the 0.05 level; and ${ }^{* * *}$ Significant at the 0.01 level; standard error \\
in brackets.
\end{tabular}

Regarding productivity, when all municipalities are included, Human Capital is the only measure that has a significant effect. However, when only county capitals are included, the reverse is true, as the Human Capital is no longer significant, while the Creative Class has a significant positive effect. Interestingly, the Recast does not have a significant effect when all municipalities are included, while it does have a significant negative effect when only county seats are investigated.

Based on these results, several important conclusions can be drawn. First, the exclusion of occupations such as business operation specialists or other financial specialists does not represent an improvement in the measurement of skills, but is in fact detrimental.

Second, the effect of the Creative Class on development is dependent on the size of the cities considered, as the effect is higher in the case of bigger municipalities, regardless of the measure used for development. This is in line with previous research, as Andersen et al. [26] concluded that the framework that Florida [22] proposes is more relevant to explain growth in the case of large urban regions.

Third, the results obtained largely confirm Florida's arguments and previous research. More specifically, he argues that Human Capital contributes to development through income. As already mentioned, the results confirm this, as Human Capital had a higher effect on income compared with the Creative Class, regardless of the cases included. However, the Creative Class has a higher effect on productivity, when county capitals are considered. As such, we concluded that these results support Florida's [22,47] arguments, with the caveat that they are valid only in the case of large urban areas.

In order to identify, at the level of our Romanian cases, the type of municipalities where the Creative Class is more connected to economic development indicators (e.g., jobs, income), we have investigated also the related scatter plots. The results show that the Creative Class has a higher influence on development in the case of large urban areas, namely the country capital and the secondary cities (e.g., Cluj-Napoca). Conversely, it has a reduced effect in the case of small industrial municipalities, where other factors can explain their level of productivity and income. These factors might include also path-dependencies, as historically they have been more developed (with their local economy more concentrated in one specific field).

In order to avoid a missing-variable bias, we further tested the theory by controlling for variables that could influence both Creative Class concentration and the development level. As already mentioned, we controlled for business diversity (Hanchman Index), business density, and path-dependency (models 1,3). Moreover, we have also excluded the capital city, Bucharest, and the second largest city, Cluj-Napoca (models 2, 4), which are outliers.

When all municipalities are included (see Table 5), the Creative Class appears to have a significant effect on income, although the effect is weaker compared with the effect of business density and path-dependency. In other words, the Creative Class predicts development regardless of business density or previous development. However, when the two outliers are excluded, the effect of the Creative Class on income is no longer statistically 
significant. In other words, the effect observed is dependent on the presence of those two cases.

Table 5. Creative Class and regional development-all municipalities.

\begin{tabular}{ccccc}
\hline & \multicolumn{2}{c}{ Income } & \multicolumn{2}{c}{ Productivity } \\
\cline { 2 - 5 } & Model 1 & Model 2 & Model 3 & Model 4 \\
\hline \multirow{2}{*}{ Creative Class } & $0.154^{* * *}$ & 0.074 & $-0.246^{* *}$ & $-0.217^{* *}$ \\
Hachman Index & -3.061 & -2.978 & -1282.03 & -1413.5 \\
Business density & $-0.099^{*}$ & -0.089 & 0.086 & 0.093 \\
& -83.424 & -77.129 & -35713.3 & -37262.6 \\
Path-Dependency & $0.467^{* * *}$ & $0.549^{* * *}$ & 0.073 & 0.063 \\
$R^{2}$ & -1.315 & -1.225 & -549.637 & -577.397 \\
Adjusted $R^{2}$ & $0.367^{* * *}$ & $0.322^{* * *}$ & $0.726^{* * *}$ & $0.666^{* * *}$ \\
F & $-0.079^{* * *}$ & -0.073 & -0.132 & -0.138 \\
Fignificant at the 0.10 level; ${ }^{* *}$ Significant at the 0.05 level; and ${ }^{* * *}$ Significant at the 0.01 level; standard error \\
in brackets.
\end{tabular}

Interestingly, in both models the Creative Class has a negative effect on productivity, when the control variables are included in the analysis, while path-dependency has a positive effect. As such, when we control for the previous levels of productivity, the presence of the Creative Class is in fact detrimental to productivity. Evidently, these results explicitly contradict Florida's theory.

Restricting the cases included in the analysis to county capitals (see Table 6) does not increase the effect that the Creative Class has on development. The Creative Class no longer has an effect on development in any of the models. However, path-dependency has a high effect on income, although the effect decreases when the outliers are excluded from the analysis. Productivity, on the other hand, is positively influenced not only by path-dependency but also by economic diversity, albeit to a lesser extent. These results support the argument made by Storper and Scott [48] that development is path dependent.

Table 6. Creative Class and regional development-county capitals.

\begin{tabular}{ccccc}
\hline & \multicolumn{2}{c}{ Income } & \multicolumn{2}{c}{ Productivity } \\
\cline { 2 - 5 } & Model 1 & Model 2 & Model 3 & Model 4 \\
\hline \multirow{2}{*}{ Creative Class } & -0.029 & -0.049 & 0.008 & 0.019 \\
& -2.625 & -2.431 & -1070.12 & -1235.64 \\
Hachman Index & 0.025 & 0.057 & $0.273^{* * *}$ & $0.299^{* *}$ \\
Business density & -71.453 & -63.105 & -31153.5 & -33053.1 \\
& 0.067 & $0.265^{* *}$ & 0.025 & 0.047 \\
Path-Dependency & -1.373 & -1.406 & -492.118 & -555.957 \\
$R^{2}$ & $0.926^{* * *}$ & $0.716^{* * *}$ & $0.743^{* * *}$ & $0.649^{* * *}$ \\
Adjusted $R^{2}$ & $-0.118^{* * *}$ & -0.135 & -0.118 & -0.133 \\
F & $0.922^{* * * *}$ & $0.846^{* * *}$ & $0.693^{* * *}$ & $0.616^{* * *}$ \\
& $0.922^{* * * *}$ & $0.846^{* * *}$ & $0.659^{* * *}$ & $0.571^{* * *}$ \\
\hline
\end{tabular}

${ }^{*}$ Significant at the 0.10 level; ${ }^{* *}$ Significant at the 0.05 level; and ${ }^{* *}$ Significant at the 0.01 level; standard error in brackets.

\section{Conclusions and Policy Lessons}

This paper contributes to the literature on regional economic development and planning by investigating the spatial and socioeconomic relevance of Creative Class theory in Romania, which we argue is a critical case for this theory. The study addressed two questions: (i) Do tolerance, talent, technology, and the territorial assets (the four T's) 
explain the presence of the members of the Creative Class in the Romanian municipalities; (ii) Is Creative Class theory a better predictor of regional development than Human Capital theory?

The main purpose of this article was to study Creative Class theory in a critical case in order to determine whether the results can be generalized to Western countries. The results partially support the relationships proposed by the theory [22]. Namely, tolerance, talent, technology and territorial assets significantly predict the geographical concentration of the Creative Class. These relationships are present when controlling for 'hard' socioeconomic conditions (unemployment), which represents an alternative explanation for the mobility of individuals $[13,62]$. However, when tolerance and diversity are considered, different types of tolerance have different effects on the Creative Class concentration. Although ethnic diversity positively predicts the concentration of creative individuals, religious diversity has a negative effect and tolerance of gay people is not significant. As such, the results support our concern regarding the ethnocentricity of the theory, as some of the characteristics of places that are considered desirable by the creative individuals in the USA and other Western counties may be not attractive to the creative individuals from other countries.

However, even though the results suggest that the presence of creative individuals is predicted by the four T's, municipalities should be cautious when deciding to apply the policy measures that the theory implies to achieve economic growth. Although the Creative Class predicts development in accordance with Florida's [22,47] arguments, the results change considerably when we control for variables that have the potential to explain development. As such, when all municipalities are considered, the relationship between the Creative Class and income is dependent on two influential data points, namely Bucuresti and Cluj-Napoca. At the same time, the Creative Class has a negative effect on productivity, a fact that explicitly contradicts Florida's theory. Moreover, when the analysis is restricted to the largest cities, the Creative Class has no effect on development in any of the models.

One main finding is that the variable that has the higher effect on regional and urban welfare in almost all cases is path-dependency, namely, the previous level of regional and urban development registered. This means that the footprints of the communist period may last longer than had been expected. Thus, the present paper brings one important contribution to the debate concerning the Creative Class. More specifically, it reflects the need for both researchers and practitioners to consider the path-dependency trajectories of urban areas. According to Storper and Scott [48] growth leads to further growth, which results in path-dependent development (known as the 'Matthew effect'). It may seem likely that complementary factors, such as, culture, entrepreneurial spirit, open access to new ideas, or favorable quality of life, may also play an important role. Therefore, we suggest that future research should more explicitly consider path-dependency, as most previous research did not consider it. At the same time, we advise that, before deciding to apply a Creative Class strategy to development, Eastern European countries have to pursue more evidence-based research to examine the critical success factors for accelerated urban and regional economic development, as the present research clearly suggests that one-size does not fit all.

Finally, we also note that Florida's initial positive conceptualization and interpretation of Creative Class theory has prompted various criticisms. Some of these critical comments have been articulated in the present study, such as his neglect of the often-specific placebased impacts of the influx of Creative Class members. Another major critique has been put forward by Storper and Scott [48], due to insufficient attention for socioeconomic equity and well-being effects of the Creative Class on the urban economy. In the longrun, a crowding-out effect might emerge, which might cause serious tensions on urban housing markets, with the consequence that a successful Creative Class might drive out less well-to-do citizens, a phenomenon called 'the new urban crisis' by Florida [52]. In our study, we did not explicitly nor comprehensively address the equity side of the Creative Class. In fact, our critical analysis of Florida's Creative Class concept is more fundamental 
in nature, since we argue that constituents of traditional Human Capital theory, e.g., on competitive regional labor markets, provide at least an equally valid explanation for the dynamic evolution of these markets. In other words, Creative Class theory does not offer a necessary and exclusive explanatory paradigm for the ups and downs of local labor markets and spatial dynamics.

Author Contributions: Conceptualization, A.M.P.; methodology, A.M.P.; software, A.M.P.; validation, A.M.P.; formal analysis, A.M.P.; investigation, A.M.P.; resources, A.M.P.; data curation, A.M.P.; writing — original draft preparation, A.M.P.; writing—review and editing, B.N., K.K. and P.N.; visualization, B.N., K.K. and P.N.; supervision, B.N., K.K. and P.N. All authors have read and agreed to the published version of the manuscript.

Funding: The authors acknowledge the grant from the Romanian Ministry of Research and Innovation, CNCS-UEFISCDI, project number PN-III-P4-ID-PCCF-2016-0166, within the PNCDI III project ReGrowEU-Advancing ground-breaking research in regional growth and development theories, through a resilience approach: toward a convergent, balanced and sustainable European Union (Iași, Romania).

Institutional Review Board Statement: Not applicable.

Informed Consent Statement: Not applicable.

Data Availability Statement: Not applicable.

Acknowledgments: The authors would like to thank to Allan Ronsenbaum, Ferenc Moksony, Shaoming Cheng and Richard Florida for the feedback they kindly provided on a draft version of this paper. Karima Kourtit and Peter Nijkamp also acknowledge the grant from the Axel och Margaret Ax:son Johnsons Stiftelse, Sweden.

Conflicts of Interest: The authors declare no conflict of interest.

\section{Appendix A}

Table A1. The Creative Class-NACE codes used.

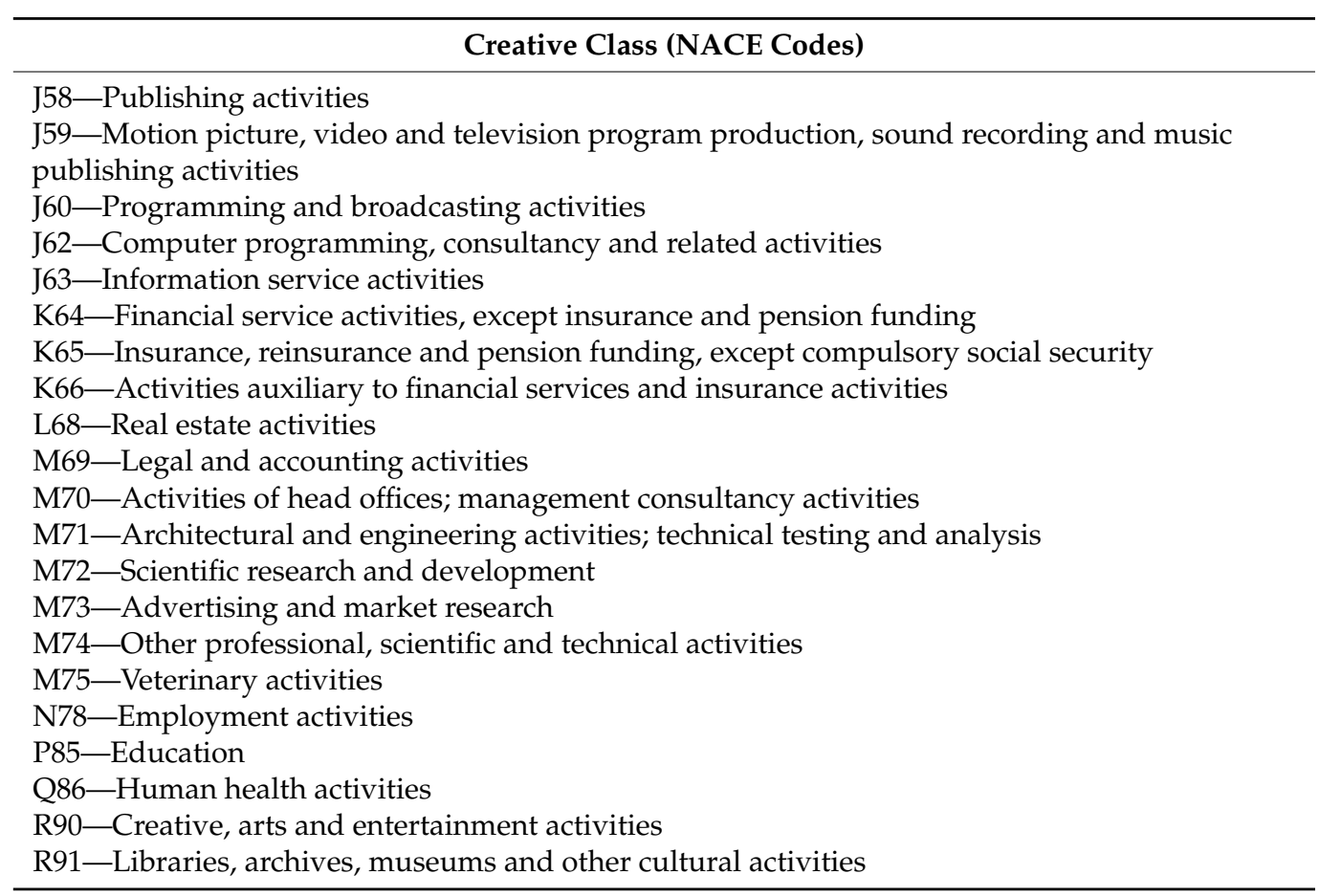




\section{Appendix B}

Table A2. Creative Class Recast.

\begin{tabular}{l} 
Creative Class Recast \\
\hline Whole sale: G46. 1; G46.2; G46.3; G46.4; G46.5; G46.6; G46.7; G46.9 \\
J58-Publishing activities \\
J59-Motion picture, video and television program production, sound recording and music \\
publishing activities \\
J60-Programming and broadcasting activities \\
J62-Computer programming, consultancy and related activities \\
J63-Information service activities \\
L68-Real estate activities \\
M69-Legal and accounting activities \\
M70-Activities of head offices; management consultancy activities \\
M71-Architectural and engineering activities; technical testing and analysis \\
M72-Scientific research and development \\
M73-Advertising and market research \\
P85.4-Higher education \\
Q86-Human health activities \\
R90-Creative, arts and entertainment activities \\
R91-Libraries, archives, museums and other cultural activities \\
\hline
\end{tabular}

\section{Appendix C}

Table A3. High-Tech NACE Codes used.

\begin{tabular}{l} 
High-Tech NACE Codes \\
\hline C21-Manufacture of basic pharmaceutical products and pharmaceutical preparations \\
C26-Manufacture of computer, electronic and optical products \\
C27-Manufacture of electrical equipment \\
C28-Manufacture of machinery and equipment \\
C29-Manufacture of motor vehicles, trailers and semi-trailers \\
C30-Manufacture of other transport equipment \\
J61-Telecommunications \\
J62-Computer programming, consultancy and related activities \\
J63-Information service activities \\
J59-Motion picture, video and television program production, sound recording and \\
music publishing activities \\
M71-Architectural and engineering activities; technical testing and analysis \\
M72-Scientific research and development
\end{tabular}

\section{References}

1. Glaeser, E.; Kourtit, K.; Nijkamp, P. (Eds.) Urban Empires; Routledge: New York, NY, USA, 2020.

2. Nijkamp, P.; Kourtit, K. The 'New Urban Europe': Global Challenges and Local Responses in the Urban Century. Eur. Plan. Stud. 2013, 21, 291-315. [CrossRef]

3. Florida, R. The Economic Geography of Talent. Ann. Am. Assoc. Geogr. 2002, 94, 743-755. [CrossRef]

4. Florida, R. The Rise of the Creative Class; Basic Books: New York, NY, USA, 2002.

5. Florida, R. Cities and the Creative Class; Routledge: New York, NY, USA, 2005.

6. Landry, C. Creative Cities; Earthscan: London, UK, 2007.

7. Kourtit, K. The New Urban World; Aachen: Shaker, OH, USA, 2019.

8. Andersson, Å.E. Creativity and Regional Development. Pap. Reg. Sci. Assoc. 1985, 56, 5-20. [CrossRef]

9. Caves, R.E. Creative Industries: Contracts between Art and Commerce; Harvard University Press: Cambridge, MA, USA, 2000.

10. Evans, G. Creative Cities, Creative Spaces and Urban Policy. Urban Stud. 2009, 46, 1003-1040. [CrossRef]

11. Batty, M. The New Science of Cities; MIT Press: Cambridge, MA, USA, 2013.

12. Cooke, P.; Lazzeretti, L. (Eds.) Creative Cities, Cultural Clusters and Local Economic Development; Edward Elgar Publishing Limited: Northampton, MA, USA, 2008. 
13. Musterd, S.; Gritsai, O. The Creative Knowledge City in Europe: Structural Conditions and Urban Policy Strategies for Competitive Cities. Eur. Urban Reg. Stud. 2012, 20, 343-359. [CrossRef]

14. Argent, N.; Tonts, M.; Jones, R.; Holmes, J. A creativity-led rural renaissance? Amenity-led migration, the creative turn and the uneven development of rural Australia. Appl. Geogr. 2013, 44, 88-98. [CrossRef]

15. Boix, R.; Capone, F.; Propris, L. Comparing Creative Industries in Europe. Eur. Urban Reg. Stud. 2014, 23, 935-940. [CrossRef]

16. Hudec, O.; Džupka, P. Culture-led Regeneration through the Young Generation: Košice as the European Capital of Culture. Eur. Urban Reg. Stud. 2014, 23, 531-538. [CrossRef]

17. Andersson, M.; Klaesson, J.; Larsson, J.P. How Local are Spatial Density Externalities? Neighbourhood Effects in Agglomeration Economies. Reg. Stud. 2016, 50, 1082-1095. [CrossRef]

18. Gong, H.; Hassink, R. Exploring the Clustering of Creative Industries. Eur. Plan. Stud. 2017, 25, 583-600. [CrossRef]

19. Navarro, J.C.; Mateos, C.; Rodríguez, M.J. Cultural Scenes, the Creative Class and Development in Spanish Municipalities. Eur. Urban Reg. Stud. 2012, 21, 301-317. [CrossRef]

20. Kourtit, K.; Nijkamp, P. Impact of Cultural Ambiance on the Spatial Distribution of Creative Professions-A Modelling Study in the Netherlands. Int. Reg. Sci. Rev. 2018, 41, 103-128. [CrossRef]

21. Kourtit, K.; Nijkamp, P. Creative Actors and Historical-Cultural Assets in Urban Regions. Reg. Stud. 2018, 53, 977-990. [CrossRef]

22. Florida, R. The Rise of the Creative Class, Revisited; Basic Books: New York, NY, USA, 2012.

23. Florida, R.; Mellander, C. The Rise of Skills: Human Capital, the Creative Class and Regional Development; CESIS Electronic Working Paper Series; Royal Institute of Technology, CESIS-Centre of Excellence for Science and Innovation Studies Paper No. 266. 2012. Available online: https:/ /ideas.repec.org/p/hhs/cesisp/0266.html (accessed on 25 April 2021).

24. Asheim, B.; Hansen, H.K. Knowledge Bases, Talents, and Contexts: On the Usefulness of the Creative Class Approach in Sweden. Econ. Geogr. 2009, 85, 425-442. [CrossRef]

25. Clifton, N. The "Creative Class" in the UK: An Initial Analysis. Geogr. Ann. Ser. B 2008, 90, 63-82. [CrossRef]

26. Andersen, K.V.; Hansen, H.K.; Isaksen, A.; Raunio, M. Nordic City Regions in the Creative Class Debate-Putting the Creative Class Thesis to a Test. Ind. Innov. 2010, 17, 215-240. [CrossRef]

27. Hansen, H.K.; Asheim, B.; Vang, J. The European Creative Class and Regional Development: How Relevant Is Florida's Theory for Europe? In Creative Economies, Creative Cities; Kong, L., O'Connor, J., Eds.; Springer: New York, NY, USA, 2009; pp. 99-120.

28. Jiang, Y.F.; Qian, Q.L.; Zhang, X.L.; Chen, Y.B. The Formation of Government-Oriented Creative Community and its Driving Mechanisms: A Case Study of the $39^{\circ}$ Space Art Creative Community in Foshan, China. Sustainability 2019, 11, 625. [CrossRef]

29. Liang, S.; Wang, Q. Cultural and Creative Industries and Urban (Re) Development in China. J. Plan. Lit. 2020, 35, 54-70. [CrossRef]

30. Patton, M.Q. Qualitative Research E Evaluation Methods: Integrative Theory and Practice, 4th ed.; SAGE Publications: New York, NY, USA, 2015.

31. Betlej, A.; Kačerauskas, T. Urban creative sustainability: The case of Lublin. Sustainability 2021, 13, 4072. [CrossRef]

32. D'Orville, H. The Relationship between Sustainability and Creativity. CADMUS 2019, 4, 65-73.

33. Felton, E.; Gibson, M.N.; Flew, T.; Graham, P.; Daniel, A. Resilient Creative Economies? Creative Industries on the Urban Fringe. Continuum 2010, 24, 619-630. [CrossRef]

34. Hansen, H.K.; Niedomysl, T. Migration of the creative class: Evidence from Sweden. J. Econ. Geogr. 2009, 9, 191-206. [CrossRef]

35. Lawton, P.; Murphy, E.; Redmond, E. Residential preferences of the 'creative class'? Cities 2013, 31, 47-56. [CrossRef]

36. Martin-Brelot, H.; Grossetti, M.; Eckert, D.; Gritsai, O.; Kovács, Z. The Spatial Mobility of the 'Creative Class': A European Perspective. Int. J. Urban Reg. Res. 2010, 34, 854-870. [CrossRef]

37. Brown, J.; Męczyński, M. 'Complexcities': Locational Choices of Creative Knowledge Workers. Built Environ. 2010, 65, $238-252$. [CrossRef]

38. Moss, G. Artistic Enclaves in the Post-Industrial City. A Case Study of Lawrenceville Pittsburgh; Springer International Publishing: Berlin/Heidelberg, Germany, 2017.

39. Glaeser, E.L. Review of Richard Florida's the Rise of the Creative Class. Reg. Sci. Urban Econ. 2005, 35, 593-596. [CrossRef]

40. Mellander, C.; Florida, R. The Rise of Skills: Human Capital, the Creative Class, and Regional Development. In Handbook of Regional Science; Fischer, M.M., Nijkamp, P., Eds.; Springer: Berlin/Heidelberg, Germany, 2014; pp. 317-329.

41. Florida, R. The Creative Class and Economic Development. Econ. Dev. Q. 2014, 28, 196-205. [CrossRef]

42. McGranahan, D.; Wojan, T. Recasting the creative class to examine growth processes in rural and urban countries. Reg. Stud. 2007, 41, 197-216. [CrossRef]

43. Marlet, G.; Van Woerkens, C. The Dutch Creative Class and How it Fosters Urban Employment Growth. Urban Stud. 2007, 44, 2605-2626. [CrossRef]

44. Rausch, S.; Negrey, C. Does The Creative Engine Run? A Consideration of the Effect of Creative Class on Economic Strength and Growth. J. Urban Aff. 2006, 28, 473-489. [CrossRef]

45. Donegan, M.; Drucker, J.; Goldstein, H.; Lowe, N.; Malizia, E. Which Indicators Explain Metropolitan Economic Performance Best? Traditional or Creative Class. J. Am. Plan. Assoc. 2008, 74, 180-195. [CrossRef]

46. Mossig, I. Regional Employment Growth in the Cultural and Creative Industries in Germany 2003-2008. Eur. Plan. Stud. 2011, 19, 967-990. [CrossRef] 
47. Florida, R.; Mellander, C.; Stolarick, K. Inside the Black Box of Regional Development-Human Capital, the Creative Class and Tolerance. J. Econ. Geogr. 2008, 8, 615-649. [CrossRef]

48. Storper, M.; Scott, A.J. Rethinking Human Capital, Creativity and Urban Growth. J. Econ. Geogr. 2009, 9, 147-167. [CrossRef]

49. Nathan, M. The Wrong Stuff? Creative Class Theory and Economic Performance in UK Cities. Can. J. Earth. Sci. 2007, 30, 433-450.

50. Krätke, S. 'Creative Cities' and the Rise of the Dealer Class: A Critique of Richard Florida's Approach to Urban Theory. Int. J. Urban Reg. Res. 2010, 34, 835-853. [CrossRef]

51. Kačerauskas, T. Indices of creative economy: Critique of R. Florida's creativity indices. Econ. Sociol. 2018, 11, 280-288. [CrossRef]

52. Florida, R. The New Urban Crisis; Basic Books: New York, NY, USA, 2017.

53. European Commission. European Commission (EC) Communication from the Commission to the European Parliament, The Council, the European Economic and Social Committee and the Committee of the Regions. Promoting Cultural and Creative Sectors for Growth and Jobs in the EU; European Commission: Brussels, Belgium, 2012.

54. European Commission. 2017 Annual Report on Intra-EU Labour Mobility Final Report January 2018; European Commission: Brussels, Belgium, 2018.

55. Cristea, M.; Mare, C.; Moldovan, C.; China, A.; Farole, T.; Vințan, A.; Park, P.; Garrett, K.P.; Ionescu-Heroiu, M. Magnet Cities. Migration and Commuting in Romania; World Bank: Washington, DC, USA, 2017.

56. Filho, D.B.F.; Paranhos, R.; Rocha, E.C.; Batista, M.; Silva, J.A.; Santos, M.L.W.D.; Marino, J.G. When is statistical significance not significant? Braz. Political Sci. Rev. 2013, 7, 31-55. [CrossRef]

57. Rapp, C. More diversity, less tolerance? The effect of type of cultural diversity on the erosion of tolerance in Swiss municipalities. Ethn. Racial Stud. 2015, 38, 1779-1797. [CrossRef]

58. Alesina, A.; Baqir, R.; Easterly, W. Public Goods and Ethnic Divisions. Q. J. Econ. 1999, 114, 1243-1284. [CrossRef]

59. Buch, T.; Hamann, S.; Niebuhr, A.; Rossen, A. How to woo the smart ones? Evaluating the determinants that particularly attract highly qualified people to cities. J. Urban Aff. 2017, 39, 764-782. [CrossRef]

60. Schumm, W.R.; Pratt, K.K.; Hartenstein, J.L.; Jenkins, B.A.; Johnson, G.A. Determining Statistical Significance (Alpha) and Reporting Statistical Trends: Controversies, Issues, and Facts. Compr. Psychol. 2013, 2. [CrossRef]

61. Bereitschaft, B.; Cammack, R. Neighborhood diversity and the creative class in Chicago. Appl. Geogr. 2015, 63, 166-183. [CrossRef]

62. Escalona-Orcao, A.I.; Sáez-Pérez, L.A.; Valverde-García, B.S. Location conditions for the clustering of creative activities in extrametropolitan areas: Analysis and evidence from Spain. Appl. Geogr. 2018, 91, 1-9. [CrossRef] 